\title{
SEARCH FOR OPTIMAL SOLUTION OF PUBLIC BUILDING RENOVATION IN TERMS OF LIFE CYCLE
}

\author{
Lina Užšilaityté ${ }^{1}$, Vytautas Martinaitis ${ }^{2}$ \\ Dept of Heating and Ventilation, Vilnius Gediminas Technical University, \\ Sauletekio al. 11, LT-10223 Vilnius, Lithuania \\ E-mails: ${ }^{1}$ Lina.Uzsilaityte@vgtu.lt; ${ }^{2}$ vsmart@vgtu.lt \\ Submitted 2 Feb. 2009; accepted 14 May 2009
}

\begin{abstract}
Climate change became a priority issue on the agenda of the energy and environmental policy of the European Union. Energy efficiency and renewable energy are the main pillars to cope with climate change. Buildings consuming $40 \%$ of final energy in the European Union play a vital role here. This is the reason for changing attitude towards evaluation of the benefits of the renovation of existing buildings. Previously before making a decision on building renovation solutions the main factor was cost-efficiency. Today life-cycle approach taking into account energy consumption and abatement of greenhouse gases is more relevant.

The goal of the paper is to compare different alternatives for the renovation of buildings taking into account energy, economic and environmental criteria while evaluating impact of renovation measures during their life cycle. The first alternative is renovation of a building up to the requirements of existing building codes. The second alternative is renovation of a building making its thermal characteristics of the envelopes by $25 \%$ better. The third alternative is renovation of a building making its thermal characteristics of the envelopes by $50 \%$ better. Possibility to use renewable energy in all the three alternatives is also investigated.

The results of analysis show that in the case under consideration replacement of district heating, mostly based on fossil fuel, with a biomass boiler has an advantage in terms of environment and energy. However, economic attractiveness of these alternatives is rather moderate. Final choice of the alternatives depends on the priorities of a decision-maker.
\end{abstract}

Keywords: public building, renovation, energy efficiency, embodied energy, life-cycle assessment, life-cycle costing, $\mathrm{CO}_{2}$ emissions, COPRAS.

\section{Introduction}

In spring of 2007 the European Council called for an ambitious integrated climate change and energy policy of the European Union. Three targets were endorsed: to achieve at least a $20 \%$ reduction of greenhouse gas emissions by 2020 compared to 1990 ; to achieve the objective of saving $20 \%$ of the European Union's energy consumption compared to projections for 2020; to achieve a binding target of a $20 \%$ share of renewable energies in overall European Union energy consumption by 2020 (Brussels European Council 2007).

Energy and Climate Change Package in the beginning of 2008 and Second Strategic Energy Review at the end of 2008 followed the decision of the European Council. In both packages the role of buildings was emphasized. This is obvious as buildings are the biggest enduser in the whole European Union. In Lithuania $40 \%$ of final energy is consumed in buildings (Department of Statistics under the Government of the Republic of Lithuania 2007). Consequently, the biggest energy saving potential exists in buildings. Proposal for a Directive of the European Parliament and of the Council on the promotion of the use of energy from renewable sources requires the member states to use minimum levels of energy from renewable sources in new or refurbished buildings in their building regulations and codes (Commission of the European Communities 2008b). Proposal for a Directive of the European Parliament and of the Council on the energy performance of buildings aims at increasing energy efficiency and use of renewable energy in buildings (Commission of the European Communities 2008a).

The above mentioned documents indicate the criteria for the evaluation of possible solutions for the renovation of existing buildings. Previously before making a decision on solutions of building renovation the main factor was cost-efficiency. It is not sufficient to use only economic criteria for decision-making any more. Therefore, alternative methods to purely economic methods are proposed. A two-factor method for appraising building renovation and energy-efficiency improvement projects allows to separate investments into those related to energy efficiency improvements, and those related to building renovation (Martinaitis et al. 2007). Using the same approach benefits of the restoration of thermal comfort can be evaluated (Užšilaitytė and Martinaitis 2007). Introduction of environmental criteria into decision-making and the choice of alternatives already in the stage of the energy audit of a building also would be expedient.

The level of energy consumption in buildings is regulated via requirements for the thermal characteristics 
and energy performance of buildings (Lietuvos Respublikos... 2005a, 2005b). These requirements constantly become stricter. Besides concepts of much more energy efficient buildings are developed worldwide. Low-energy buildings are designed, built and investigated (Karlsson and Moshfegh 2007; Thyholt and Hestnes 2008). Also, zero-energy or buildings producing energy are designed. Concepts of green or sustainable buildings are developed. Green building construction can result in significant economic savings by improving employee productivity, increasing benefits from improvements in health and safety, and providing savings from energy, maintenance, and operational costs (Pan and Huang 2008; Ries and Bilec 2006). These concepts consequently become a good practise for architects, engineers and finally for policymakers.

The biggest opportunities and relatively unlimited possibilities to create an energy-efficient building exist when a new building is designed. Much more limits are faced during renovation of existing buildings. As these buildings are already built in a certain geographical orientation, they already have particular construction elements, dependence on previously-made engineering solutions, etc. Although the scope of construction of new buildings grew rapidly during the last years, there are still much more old buildings in Lithuania. $89 \%$ of buildings are constructed before 1990 (Nacionalinè žemès tarnyba prie Žemès ūkio ministerijos and valstybès imonè Registru centras 2008). A large share of them requires renovation. Very often initiative to renovate buildings belongs to the state or local governments. If a private owner is mostly interested in the cost of renovation, governments should pay a wider attitude towards the consequences of the renovation financed from their budget. Sometimes a question is posed what is more expedient - to renovate a building or to demolish it and build a new one. Investigations show that renovation of a building is more beneficial in terms of economic, environmental and social issues (Dong et al. 2005; Erlandsson and Levin 2005; Power 2008).

Attitude towards renovation of a building should be based on the concept of sustainable development. While renovating a building a number of problems can be solved: depletion of natural resources, pollution of the environment, and increase of social welfare. Depletion of natural resources is a sensitive issue. Stock of fossil fuels is limited. However, possibilities for development without further use of energy resources is impossible. In some regions development is restricted and poverty is confronted because of unavailable energy supply. Therefore, conservation of energy resources and search for alternative energy resources is of great importance. While using energy resources pollution of the environment is unavoidable. However, it is possible to optimize possible pollution from an object if the estimation will be made at the design stage. By optimizing the use of natural resources the problems of social welfare are solved: thermal comfort is ensured and bills for energy consumption are reduced. Buildings are the biggest end-users. Therefore, substantial contribution to solving the above men- tioned problems can be ensured while designing new and old buildings under renovation.

The energy sector is the main emitter of greenhouse gases. Renovation of buildings besides the energy-saving benefits generates environmental benefits by decreasing the air pollution. Impacts of the air pollution impose costs on society which are often not at all or only partly considered in the production cost and in the market prices of respective products or services. In addition, greenhouse gases, especially $\mathrm{CO}_{2}$ emissions, released from fossil fuel combustion constitute another source of social damages, in particular to forthcoming generations. The existence of these costs - the so-called external costs - constitute a severe market failure leading to the misallocation of scarce resources, since producers and consumers come to decisions that may be optimal for them but not for society as a whole (Diakoulaki et al. 2007). It is argued that costs of the damage to society entailed by the emissions of greenhouse gases have to be included into the cost of energy or product, otherwise it is borne by society now or in the future (Karlsson and Gustavsson 2003). This can be done via taxes or market instruments such as emission trading. Tax of emissions should be at a level to encourage the emitter invest into technologies reducing emissions. Today carbon dioxide $\left(\mathrm{CO}_{2}\right)$ has its monetary value in the whole European Union. Trade of $\mathrm{CO}_{2}$ takes place in the European Union emission trading system and under Kyoto Protocol (Directive 2003/87/EC... 2003; United Nations... 1998). The price of $\mathrm{CO}_{2}$ is intermittent, however, it is forecasted that it may grow substantially in the future after the beginning of a new European Union emission trading period.

While looking for the alternatives of economic calculations allowing evaluation of the alternatives in terms of sustainability, methods based on thermodynamics are applied more widely. Exergy and emergy analyses are used for the evaluation of various engineering systems (Sciubba and Ulgiati 2005; Yang et al. 2008). In order to meet the idea of exergy and emergy analyses, analysers with technological background come with the definition of embodied energy. Embodied energy is the amount of energy consumed to create a product, material or service. Traditionally only energy used during operation of an object is taken into account. However, in some cases energy used for the creation of an object can change the results of the estimation of benefits of the process. It is especially relevant while designing low-energy buildings.

Life-cycle assessment is a tool allowing integrating thermodynamic, economic and environmental considerations into one method. This tool creates possibilities to achieve wider attitude to the building impact on the environment, economy and to create buildings taking into account the concept of sustainable development. Many scientific analyses are made in this field (Arena and de Rosa 2003; Citherlet and Defaux 2007; Johansson 2009; Martinaitis 2001; Karlsson and Moshfegh 2007; Sartori and Hestnes 2007; Scheuer et al. 2003; Yang et al. 2008).

The goal of this paper is to investigate alternatives of the renovation of a public building taking into account substantial increase of its energy efficiency and possibil- 
ity to use renewable energy and compare different alternatives taking into account energy, economic and environmental criteria while evaluating renovation impact during its life cycle. The task is to use multi-criteria approach in the evaluation of different alternatives.

\section{Methodology}

In this section the methodology used for the evaluation of impact of different building renovation alternatives is described.

The object of investigation is a building and its heating and ventilation systems. Lighting systems are not considered here.

The baseline is an old depreciated building, which requires renovation and making it more energy- and environmentally efficient. It is assumed that all the envelopes of the building and its heating and ventilation systems are renovated. Seeking to renovate the building, there can be numerous alternatives under consideration, combining particular energy-saving measures and alternatives to use renewable energy.

The task is to make a comprehensive evaluation of the alternatives, while estimating energy, economic and environmental benefits of each alternative under consideration. Therefore, evaluation is made using life-cycle analysis. Energy evaluation is performed in terms of primary energy during the lifetime of the building renovation measures. Environmental evaluation is performed while evaluating $\mathrm{CO}_{2}$ emissions generated because of the renovation of the building. Life-cycle costing is performed for the economic evaluation of the alternatives.

Six alternatives are chosen for possible renovation of the building. The first alternative is reconstruction of the building to meet existing requirements of building thermal characteristics which are valid in Lithuania (Lietuvos Respublikos... 2005b). The second alternative is renovation of the building making its thermal characteristics of the envelopes by $25 \%$ better than in existing regulations. The third alternative is renovation of the building making its thermal characteristics of the envelopes by $50 \%$ better. Possibility to install a biomass boiler instead of existing district heating for heat production in all the three alternatives is investigated.

The task of the evaluation process of alternatives is to estimate the energy, environmental and economic efficiencies.

Energy efficiency is understood as the impact of building renovation measures on the building energy consumption after renovation. In order to decrease energy consumption of the heating system, a certain amount of energy has to be embodied into a building together with insulation, new engineering systems, etc. during renovation. In order to evaluate the benefits of renovation measures during their life cycle, energy consumption has to be divided into two components. The first component is primary energy embodied into the building with the renovation measures (hereinafter - embodied energy), i. e. primary energy used for the creation and installation of renovation measures in a building. The second component is operational energy, i. e. primary energy used for heating and ventilation of the building during the considered lifetime of the renovation package. The most energyefficient alternative is the one which has the lowest sum of these two components:

$$
E E+O E=\min (T E)
$$

where EE - embodied energy, MWh, OE - operational energy, MWh, TE - total primary energy consumed during the lifetime of renovation measures package in a building (hereinafter - total energy consumption), MWh.

Energy efficiency can be estimated using various indicators. In this case these comparative indicators (calculated per unit of the building area) are proposed:

1) annual heat consumption per unit of the building area after reconstruction $\left(\mathrm{kWh} / \mathrm{m}^{2}\right)$. This indicator is necessary for the comparison of energy characteristics with those of other existing and designed buildings,

2) embodied energy per unit of the building area $\left(\mathrm{kWh} / \mathrm{m}^{2}\right)$. This indicator allows comparing energy used for implementation of renovation measures with the energy used for operation of a building after implementation of these measures,

3) operational energy per unit of the building area $\left(\mathrm{kWh} / \mathrm{m}^{2}\right)$,

4) total energy consumption per unit of the building area $\left(\mathrm{kWh} / \mathrm{m}^{2}\right)$,

5) saved energy because of the implemented renovation measures (\%). This indicator is calculated in terms of primary energy savings during renovation measure lifetime.

Environmental efficiency is understood as the effect of the implemented renovation measures on $\mathrm{CO}_{2}$ emissions. Comprehensive analysis would require evaluating all the greenhouse gases emitted. In this paper the task was to estimate the monetary value of the emissions. Therefore, only $\mathrm{CO}_{2}$ emissions were chosen because they already have their monetary value under the emission trading scheme. Two indicators are proposed:

1. total $\mathrm{CO}_{2}$ emissions generated because of the implemented renovation measures. This is the sum of the emissions, generated during operation of the building after renovations, and the emissions generated because of the renovation itself (embodied $\mathrm{CO}_{2}$ emissions) (tons of $\mathrm{CO}_{2}$ ). This indicator shows the impact on the environment of each alternative;

2. avoided $\mathrm{CO}_{2}$ emissions because of the implemented renovation measures (tons of $\mathrm{CO}_{2}$ ). This indicator shows the benefit of each renovation alternative for the environment.

Economic efficiency is understood as an economic benefit generated by renovation measures. Life-cycle costing method is proposed for evaluation of this benefit (Fuller and Petersen 1995). Life-cycle costing allows comprehensive evaluation of the initial investments and operational expenses. Even if the initial investments are higher, total costs during the life cycle (hereinafter LCC) of the considered renovation measures package can be lower when the operational costs are evaluated. Also, this method allows assessing the value of money in the considered time period. Three economic efficiency indicators are proposed: 
1) LCC (LTL). This indicator gives a comprehensive economic evaluation of the renovation alternative;

2) total saved expenses because of the renovation of the building. This is the sum of the avoided $\mathrm{CO}_{2}$ costs and saved operational costs (LTL). It is assumed that the cost of $\mathrm{CO}_{2}$ is $25 \mathrm{EUR} /$ ton $\mathrm{CO}_{2}$. This indicator shows monetary benefit of the renovation alternative;

3) investments (LTL). This indicator has primary importance for decision-making when financing possibilities of renovation are limited.

The most convenient evaluation method could be the one which gives one answer to a question. But it is not the case for the comprehensive evaluation of the subject. The more comprehensive is analysis, the more indicators will be used. Various decision- making tools are used to solve the problem of coping with a number of indictors obtained during analysis - multi-criteria analysis, artificial neural network, genetic algorithm (Adedeji 2008; Kaklauskas et al. 2005; Rogoža et al. 2006; Yalcintas 2008; Zavadskas et al. 2009). In this paper multi-criteria analysis will be used to get an answer to the question which alternative is the most optimal. Multiple criteria complex proportional evaluation and determination of the utility degree and value methods are chosen for prioritisation of projects. According to the multiple criteria complex proportional evaluation method (COPRAS), prioritisation and significance of the alternative is proportionally dependent on the system of criteria describing the alternative, the values of these criteria and importance of each criteria. According to the determination of the utility degree and value method, the utility degree of the alternative is calculated in terms of the percentage which determines the level of the achieved goals and satisfied demands. The most optimal alternative has the highest utility degree (Banaitienè et al. 2008).

Seeking the goal of investigation to evaluate the impact of the building renovation measures during their lifetime the evaluation process is proposed:

1. In the first stage the main parameters of the building are estimated and information required for the estimation of the energy consumption level of the building is collected. Assessment and normalisation (for external and internal air temperature conditions and duration of the heating season which affect actual energy use) of the actual energy consumption for heating is performed. Also, the required level of reconstruction is determined.

2 . In the second stage number of alternatives is chosen and the scope of the alternatives is determined.

3. In the third stage estimation of energy efficiency of the renovation measures is performed. Annual heat consumption per unit of the building area after the reconstruction is estimated, operational energy consumption and annual energy savings of each alternative are calculated.

4. In the fourth stage life-cycle assessment of the alternatives under consideration is performed. Inventory analysis is performed and impact assessment is made (embodied energy, total energy consumption, primary energy savings and $\mathrm{CO}_{2}$ emissions are calculated).
5. In the fifth stage cost-efficiency of each alternative is estimated. Investments, LCC and total saved expenses are calculated.

6. In the sixth stage indicator analysis is performed and choice of the alternative is made. Alternatives are prioritised using 4 main indicators. Energy indicator: saved energy which has to be maximal. Environmental indicator: avoided $\mathrm{CO}_{2}$ emissions, which has to be maximal. Economic indicators: LCC, which have to be minimal and investments, which have to be minimal. LCC is a comprehensive economic criterion, however, the size of investments as an additional criterion is chosen because investment capacity usually is a restrictive factor limiting possibilities to invest into more energetically or environmentally friendly projects. It is assumed that all the indictors are equal in their importance.

It is assumed that at the moment of investigation of the building renovation, the building already has a particular amount of embodied energy and operational energy used. This can be considered constant and further consumption will depend on the decision on the renovation of the building. Therefore, it is not necessary to perform life-cycle assessment of the whole existing building as it will not affect final results. Renovation measures are considered as a separate unit.

\section{Results and discussion}

An educational institution building is analysed according to the methodology proposed in part 2 of this paper. The building was built in Vilnius in 1984. It is a three-storey building. The area of the building is $4737 \mathrm{~m}^{2}$. Heat is supplied via the district heating system. The envelopes of the building are deteriorated and do not meet existing requirements. The heating system except the heat substation is depreciated. A new modern heating substation is installed in the building. The ventilation system is depreciated and not in exploitation any more. Normalised annual heat consumption of the building is $264 \mathrm{kWh} / \mathrm{m}^{2}$.

Six alternatives of the building reconstruction are analysed:

1. The building is reconstructed to meet existing requirements for its thermal characteristics, new heating and ventilation systems are installed (Unorm).

2 . The building is reconstructed to meet by $25 \%$ better thermal characteristics than existing requirements, new heating and ventilation systems are installed (U25).

3 . The building is reconstructed to meet by $50 \%$ better thermal characteristics than existing requirements, new heating and ventilation systems are installed (U50).

4. The building is reconstructed to meet existing requirements for its thermal characteristics, new heating and ventilation systems, a biomass boiler are installed (Unorm+Bio).

5 . The building is reconstructed to meet by $25 \%$ better thermal characteristics than existing requirements, new heating and ventilation systems, biomass boiler are installed (U25+Bio).

6 . The building is reconstructed to meet by $50 \%$ better thermal characteristics than existing requirements, 
new heating and ventilation systems, a biomass boiler are installed (U50+Bio).

The values of heat transmission coefficients of the envelopes of each alternative are presented in Table 1.

Table 1. Envelope heat transmission coefficient of each alternative

\begin{tabular}{l|c|c|c|c}
\hline \multirow{2}{*}{$\begin{array}{c}\text { Envelope } \\
\text { type }\end{array}$} & \multicolumn{4}{|c}{$\begin{array}{c}\text { Heat transmission coefficients, } \\
\mathrm{W} /\left(\mathrm{m}^{2} \cdot \mathrm{K}\right) / \text { Alternatives }\end{array}$} \\
\cline { 2 - 5 } & $\begin{array}{c}\text { Existing } \\
\text { situation }\end{array}$ & $\begin{array}{c}\text { Unorm \& } \\
\text { Unorm+Bio }\end{array}$ & $\begin{array}{c}\text { U25 \& } \\
\text { U25+Bio }\end{array}$ & $\begin{array}{c}\text { U50 \& } \\
\text { U50+Bio }\end{array}$ \\
\hline Walls & 1.10 & 0.28 & 0.20 & 0.14 \\
\hline Roof & 1.10 & 0.21 & 0.17 & 0.11 \\
\hline Windows & 2.56 & 1.82 & 1.36 & 0.90 \\
\hline Doors & 2.30 & 1.80 & 1.35 & 0.90 \\
\hline Floor & 0.64 & 0.22 & 0.17 & 0.11 \\
\hline
\end{tabular}

As it is presented in Table 1, heat transmission coefficients of the existing building are very high, what determines a high heat demand of the building. Even heat transmission coefficients of alternatives 1 and 4 , which comply with existing building regulations, are 4 times lower for walls, 5 times lower for roof, almost 2 times lower for windows, almost 3 times lower for floors.

Alternatives Unorm and Unorm+Bio reduce annual heat consumption by $61 \%$, alternatives U25 and U25+Bio reduce annual heat consumption by $68 \%$, alternatives $\mathrm{U} 50$ and $\mathrm{U} 50+\mathrm{Bio}$ reduce annual heat consumption by $75 \%$.

It is assumed that the lifetime of the package of building renovation measures is 20 years.

There exist some boundaries for the life-cycle assessment of the energy-saving measures considered. The assumptions made are given below.

1. In the case of renovation of the building envelopes, only insulation is considered in the inventory analysis. It is assumed that additional materials required have a little impact on the life-cycle consumption and have a negligible impact on the results of calculations.

2 . In the case of renovation of the heating system, only heating devices, pipes and insulation are considered in the inventory analysis, because these are the main components having an impact on the life-cycle consumption (Martinaitis 2001; Sasnauskaite 2007). In the case of reconstruction of the ventilation system, the ventilation unit and ducts are considered in the inventory analysis.

3 . The life-cycle phases of renovation measures under consideration - extraction and production of the raw materials, production of elements of the envelopes, heating and ventilation systems, transportation of the elements to the building lot and operation of the building:

3.1. Only the main materials, which have the biggest impact on the renovation measure life-cycle balance, are considered - steel (heating devices, pipes, ducts, ventilation unit, boiler), aluminium (air-handling unit), mineral wool (envelopes and pipe insulation), polyvinylchloride and glass (windows, doors).

3.2. Production of different elements of the renovation measures was evaluated because of unavailable data.
3.3. While assessing the transportation phase of the renovation measure elements, it was assumed that some elements would be produced in Lithuania (insulation, windows, doors, ducts, boiler, air-handling unit); some of them would be imported from abroad (pipes, radiators).

3.4. Primary energy demand for the operation of heating and ventilation systems is estimated, taking into account heat and electricity use.

3.5. Due to the lack of data, negligible importance and unknown behaviour of the user in advance of particular phases, design, packaging, reuse, recycling and final disposal phases are not taken into consideration.

The results of the alternative energy efficiency are presented in Table 2 and Fig. 1.

According to the results (see Fig. 1), the most optimal alternative in terms of energy is alternative U50+Bio even if it has the highest share of embodied energy. In this case the thermal characteristics of the building are by $50 \%$ better than existing requirements of the regulation. Total energy consumption is equal to $2615 \mathrm{kWh} / \mathrm{m}^{2}$. The least energy-efficient alternative is alternative Unorm when the building meets existing thermal requirements and heat is supplied through the district heating system (total life-cycle energy consumption equals $3708 \mathrm{kWh} / \mathrm{m}^{2}$ ).

The results of the environmental evaluation are presented in Fig. 2. Improvement of energy efficiency of the building has a positive effect on reduction of $\mathrm{CO}_{2}$ emissions. The biggest effect is achieved introducing renewable energy sources into production of heat for the building. As it is seen in alternatives, installation of a biomass boiler instead of existing district heating has a significant positive environmental effect, as no $\mathrm{CO}_{2}$

Table 2. Annual heat consumption and primary savings of alternatives

\begin{tabular}{l|c|c}
\hline \multicolumn{1}{c|}{ Alternatives } & $\begin{array}{c}\text { Annual heat } \\
\text { consumption, } \\
\mathrm{kWh} / \mathrm{m}^{2}\end{array}$ & $\begin{array}{c}\text { Primary energy } \\
\text { savings, } \\
\%\end{array}$ \\
\hline Existing situation & 264 & - \\
\hline Unorm & 103 & 48 \\
\hline U25 & 86 & 55 \\
\hline U50 & 67 & 61 \\
\hline Unorm+Bio & 103 & 53 \\
\hline U25+Bio & 86 & 58 \\
\hline U50+Bio & 67 & 64 \\
\hline
\end{tabular}

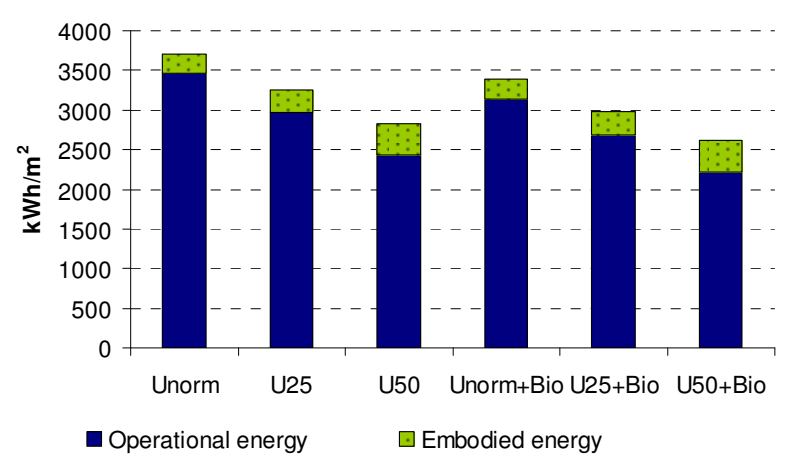

Fig. 1. Life-cycle energy consumption of each alternative 


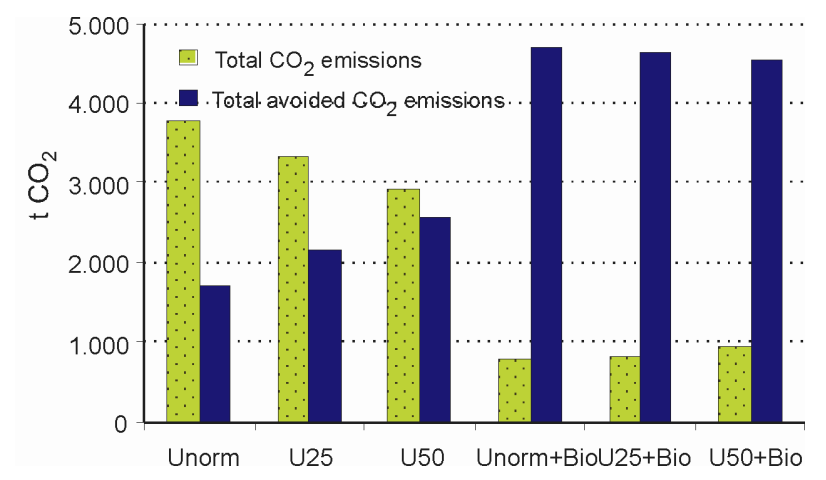

Fig. 2. Environmental efficiency of alternatives

emissions occur during the operation of the building because biomass is considered $\mathrm{CO}_{2}$ neutral fuel. Similar results would be attained if heat supplied via the district heating network would be produced from biomass.

In alternatives without a biomass boiler, $\mathrm{CO}_{2}$ emissions decrease with the improvement of the building energy efficiency. In the case of alternatives with a biomass boiler, $\mathrm{CO}_{2}$ emissions increase in more energy-efficient alternatives because the amount of embodied energy is higher in a more energy-efficient building. The highest avoided emissions occur in alternative Unorm+Bio even if alternative U50+Bio is the most energy-efficient alternative.

Alternatives with a biomass boiler have an obvious advantage from the environmental point of view. Additional benefit in this case can be added to the point of use of local fuel.

The results of economic calculations are presented in Fig. 3. Economic calculations are made according to the current construction and energy prices. The more building thermal characteristics are improved, the less costefficient a project becomes. Operational expenses decrease with each improvement of the building thermal characteristics. The best alternative in terms of LCC is alternative Unorm. It has the lowest costs during the life cycle of energy-saving measure package -5.7 mio LTL. The main factor of these results is the lowest investment costs. Alternative U50+Bio has the highest LCC 7.1 mio LTL. However, alternative Unorm has the highest operational costs. Alternative U50+Bio has the lowest

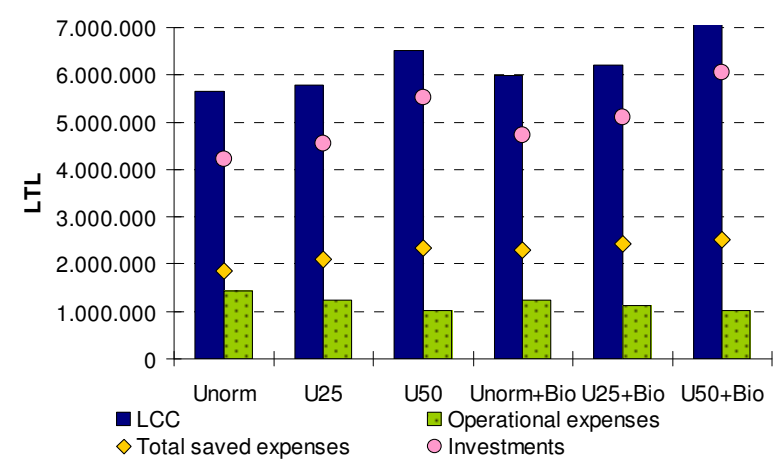

Fig. 3. Economic efficiency of alternatives operational costs, because heat produced from biomass is cheaper than heat supplied via the district heating which is app. by $90 \%$ based on fossil fuel.

The lowest investments are required for alternative Unorm - 4.2 mio LTL. The highest investments are required for alternative U50+Bio - 6.1 mio LTL, what is by $43 \%$ more expensive than alternative Unorm.

The choice of alternative depends on the priorities of a decision-maker. Alternative U50+Bio is the best in terms of energy. Alternative Unorm is the best in terms of economy. Alternative Unorm+Bio is the best in terms of the environment.

The results of multi-criteria analysis are presented in Fig. 4. The chosen criteria for the analysis have different measurement units, therefore, the criteria values are recalculated to dimensionless values according to the methodology presented in (Zavadskas et al. 2001). Assuming that all the 4 criteria are equal in their importance, the most optimal alternative is alternative Unorm+Bio. But the difference between alternative Unorm+Bio and alternative $\mathrm{U} 25+\mathrm{Bio}$ is negligible.

Alternatives with a biomass boiler have a higher utility degree than alternatives without a biomass boiler. In the case of alternatives without a biomass boiler priority is given to more energy-efficient alternatives. In the case of alternatives with a biomass boiler a less energyefficient alternative has a higher importance.

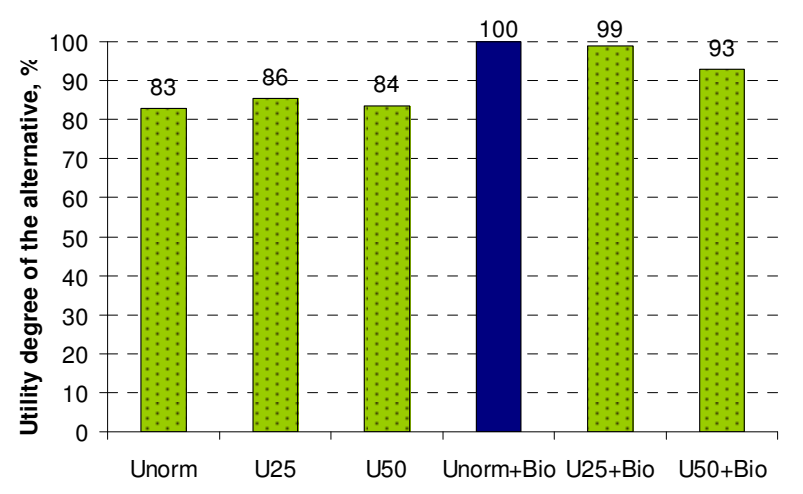

Fig. 4. Results of multi-criteria analysis

Giving different values for weight coefficients or changing the criteria used for decision-making would change the final results. In the case under consideration, if only three criteria were used (for example, saved energy, avoided $\mathrm{CO}_{2}$ emissions and LCC) - one criteria for each indicator - the utility degree of the alternatives without a biomass boiler would decrease, alternative U25+Bio would have the highest priority and alternative U50 would have the highest priority among the cases without a biomass boiler, as economic indicators would have a less importance. Additional changes would be created if the values of weight coefficients would be different. However, the number of criteria and their importance depend on a decision-maker and his priorities or demands. 


\section{Conclusions}

1. Introduction of possibilities to replace fossil fuel with renewable energy into the alternatives gives a positive environmental effect. Introduction of other than biomass types of non-purchasable renewable energy would have additional benefits from the point of view of energy.

2 . From the point of view of energy, the best is alternative U50+Bio when building thermal characteristics are by $50 \%$ better than existing requirements of the regulation and a biomass boiler is installed instead of existing district heating supply of energy. In this case annual heat consumption of the building accounts for $67 \mathrm{kWh} / \mathrm{m}^{2}$ and total primary energy consumption equals $2615 \mathrm{kWh} / \mathrm{m}^{2}$. Total primary energy savings account for almost $64 \%$ in comparison with the case if no renovation would be made.

3. Alternative Unorm+Bio is the most attractive in terms of environment because of the lowest $\mathrm{CO}_{2}$ emissions during the lifetime of renovation measures and the biggest amount of avoided $\mathrm{CO}_{2}$ emissions.

4. Alternative Unorm is the most attractive in terms of economy because of the lowest LCC and the lowest investments.

5. The choice of an alternative depends on the priorities of a decision-maker. If all the chosen criteria are treated equally, the alternative U25+Bio is the most optimal. However, economic attractiveness of this alternative is low. Economic attractiveness of this alternative would increase with increase of heat and $\mathrm{CO}_{2}$ prices, decrease of the required investments into a biomass boiler house and operational costs.

6 . The results of the study show that, seeking that renovation process would comply with the sustainable development concept, it is expedient to make preliminary evaluations of the life-cycle impact of the renovation measures already in the stage of building energy audit.

\section{References}

Adedeji, A. A. 2008. Design approach for low-exergy consumption for building service life, in Proceedings of the $7^{\text {th }}$ International conference "Environmental Engineering", Vol. 2. Vilnius: Technika, 773-778.

Arena, A. P.; de Rosa, C. 2003. Life cycle assessment of energy and environmental implications of the implementation of conservation technologies in school buildings in Mendoza - Argentina, Building and Environment 38: 359368. doi:10.1016/S0360-1323(02)00056-2

Banaitienè, N.; Banaitis, A.; Kaklauskas, A.; Zavadskas, E. K. 2008. Evaluating the life cycle of a building: A multivariant and multiple criteria approach, Omega - International Journal of Management Science 36(3): 429-441. doi:10.1016/j.omega.2005.10.010

Council of the European Union. 2007. Brussels European Council 8/9 March 2007, Presidency Conclusions [cited 3 January 2009]. Available from Internet: < register. consilium.europa.eu $>$.

Citherlet, S.; Defaux, T. 2007. Energy and environmental comparison of three variants of a family house during its whole lifespan, Building and Environment 42: 591-598. doi:10.1016/j.buildenv.2005.09.025
Commission of the European Communities. 2008a. Proposal for a directive of the European Parliament and of the Council on the energy performance of buildings [cited 3 January 2009]. Available from Internet: <eur-lex.europa.eu>.

Commission of the European Communities. 2008b. Proposal for a directive of the European Parliament and of the Council on the promotion of the use of energy from renewable sources [cited 3 January 2009]. Available from Internet: $<$ eur-lex.europa.eu >.

Department of Statistics under the Government of the Republic of Lithuania. 2007. Energy balance 2007, Vilnius: Department of Statistics under the Government of the Republic of Lithuania. $52 \mathrm{p}$.

Diakoulaki, D.; Mirasgedis, S.; Tourkolias, C. 2007. Assessment and exploitation of energy-related externalities in the industrial sector, Energy Policy 35: 2925-2938. doi:10.1016/j.enpol.2006.10.021

Directive 2003/87/EC of the European Parliament and of the Council of 13 October 2003 establishing a scheme for greenhouse gas emission allowance trading within the Community and amending Council Directive 96/61/EC. 2003, Official Journal of the European Union L 275: 32-46.

Dong, B.; Kennedy, Ch.; Pressnail, K. 2005. Comparing life cycle implication of building retrofit and replacement options, Canadian Journal of Civil Engineering 32: 10511063. doi:10.1139/105-061

Erlandsson, M.; Levin, P. 2005. Environmental assessment of rebuilding and possible performance improvements effect on a national scale, Building and Environment 40: 14591471.

Fuller, S. K.; Petersen, S. R. 1996. Life-cycle costing manual for the Federal energy management program. NIST Handbook. Washington: US Government printing office. $224 \mathrm{p}$.

Johansson, D. 2009. The life cycle costs of indoor climate systems in dwellings and offices taking into account system choice, airflow rate, health and productivity, Building and Environment 44: 368-376. doi:10.1016/j.buildenv.2008.03.011

Kaklauskas, A.; Zavadskas, E. K.; Raslanas, S. 2005. Multivariant design and multiple criteria analysis of building refurbishments, Energy and Buildings 37(4): 361-372. doi:10.1016/j.enbuild.2004.07.005

Karlsson, A.; Gustavsson, L. 2003. External costs and taxes in heat supply systems, Energy Policy 31: 1541-1560. doi:10.1016/S0301-4215(02)00222-7

Karlsson, J. F.; Moshfegh, B. 2007. A comprehensive investigation of a low-energy building in Sweden, Renewable Energy 32: 1830-1841. doi:10.1016/j.renene.2006.10.009

Lietuvos Respublikos aplinkos ministro $2005 \mathrm{~m}$. gruodžio $20 \mathrm{~d}$. isakymas Nr. D1-624, „Dèl statybos techninio reglamento STR 2.01.09:2005 „Pastatu energinis naudingumas, energinio naudingumo sertifikavimas" patvirtinimo", Valstybès žinios, 2005a, 151-5568.

Lietuvos Respublikos aplinkos ministro $2005 \mathrm{~m}$. kovo $18 \mathrm{~d}$. isakymas Nr. D1-156 „Dèl statybos techninio reglamento STR 2.05.01:2005 „Pastatu atitvaru šiluminè technika“ patvirtinimo“, Valstybès žinios, 2005b, 100-3733.

Martinaitis, V.; Kazakevičius, E.; Vitkauskas, A. 2007. A twofactor method for appraising building renovation and energy efficiency improvement projects, Energy Policy 35: 192-201. doi:10.1016/j.enpol.2005.11.003

Martinaitis, V. 2001. Pastato gyvavimo ciklo termodinamines analizés modelis [Thermodynamical analysis of the building life cycle]. Vilnius: Technika. 172 p. 
Nacionalinė žemės tarnyba prie Žemės ūkio ministerijos, valstybės įmonė Registrų centras. 2008. Lietuvos Respublikos nekilnojamojo turto registre įregistruotų statinių apskaitos duomenys $2008 \mathrm{~m}$. sausio $1 \mathrm{~d}$. [cited 15 January 2009]. Available from Internet: <www.nzt.lt $>$.

Pan, Y.; Yin, R.; Huang, Z. 2008. Energy modelling of two office buildings with data center for green building design, Energy and Buildings 40: 1145-1152.

Power, A. 2008. Does demolition or refurbishment of old and inefficient homes to help to increase our environmental, social and economic, viability? Energy Policy 36: 4487 4501. doi:10.1016/j.enpol.2008.09.022

Ries, R.; Bilec, M. M. 2006. The economic benefits of green buildings: A comprehensive study, The Engineering Economist 51: 259-295. doi:10.1080/00137910600865469

Rogoža, A.; Čiuprinskas, K.; Šiupšinskas, G. 2006. The optimisation of energy systems by using 3E factor: the case studies, Journal of Civil Engineering and Management 12(1): 63-68.

Sartori, I.; Hestnes, A. G. 2007. Energy use in the life-cycle of conventional and low energy buildings: A review article, Energy and Buildings 39: 249-257. doi:10.1016/j.enbuild.2006.07.001

Sasnauskaitè, V.; Užšilaitytè, L.; Rogoža, A. 2007. A sustainable analysis of a detached house heating system throughout its life cycle. A case study, International Journal of Strategic Property Management 11(3): 143-155.

Scheuer, Ch.; Keoleian, G.; A.; Reppe, P. 2003. Life cycle energy and environmental performance of a new university building: modelling challenges and design implications, Energy and Buildings 35: 1049-1064. doi:10.1016/S0378-7788(03)00066-5
Sciubba, E.; Ulgiati, S. 2005. Emergy and exergy analyses: Complementary methods or irreducible ideological options? Energy 30: 1953-1988. doi:10.1016/j.energy.2004.08.003

Thyholt, M.; Hestnes, A. G. 2008. Heat supply to low-energy buildings in district heating areas Analyses of $\mathrm{CO}_{2}$ emissions and electricity supply security, Energy and Buildings 40: 131-139. doi:10.1016/j.enbuild.2007.01.016

United Nations Kyoto Protocol to the United Nations Framework Convention on Climate Change. 1998 [cited 3 January 2009]. Available from Internet: <http://unfccc.int>.

Užšilaitytè, L.; Martinaitis, V. 2007. Igyvendintų energijos taupymo projektų Lietuvos mokyklų pastatuose efektyvumo vertinimas [Efficiency evaluation of the implemented energy saving projects in Lithuanian schools buildings] [CD], in The Conference of Young Scientists on Energy Issues Proceedings, 7 June 2007, Kaunas.

Yalcintas, M. 2008. Energy-savings predictions for buildingequipment retrofits, Energy and Buildings 40: 2111-2120. doi:10.1016/j.enbuild.2008.06.008

Yang, L.; Zmeureanu, R.; Rivard, H. 2008. Comparison of environmental impacts of two residential heating systems, Building and Environment 43: 1072-1081. doi:10.1016/j.buildenv.2007.02.007

Zavadskas, E. K.; Kaklauskas, A.; Turskis, Z.; Kalibatas, D. 2009. An approach to multi-attribute assessment of indoor environment before and after refurbishment of dwellings, Journal of Environmental Engineering and Landscape Management 17(1): 5-11. doi:10.3846/1648-6897.2009.17.5-11

\section{VISUOMENINIO PASTATO OPTIMALAUS RENOVACIJOS SPRENDIMO PAIEŠKA, ATSIŽVELGIANT I ENERGETINIUS, APLINKOS APSAUGOS IR EKONOMINIUS KRITERIJUS}

\section{Užšilaitytė, V. Martinaitis}

Santrauka

Klimato kaita tapo prioritetiniu punktu Europos Sajungos energetikos ir aplinkosaugos politikos darbotvarkejje. Energijos vartojimo efektyvumas ir atsinaujinantys energijos ištekliai - pagrindinès nuostatos siekiant iveikti klimato kaitos keliamas problemas. Pastatams, kuriuose suvartojama $40 \%$ Europos Sajungos galutinès energijos, čia tenka pagrindinis vaidmuo. Tai yra priežastis keisti požiūrí, vertinant esamų pastatų renovavimo naudą. Anksčiau prieš priimant sprendimą dẻl pastatų renovacijos pagrindinis faktorius buvo ekonominis efektyvumas. Šiandien tikslingiau yra atsižvelgti i gyvavimo ciklą, i̇vertinant energijos suvartojimo mastus ir šiltnamio dujų išmetimus. Šio darbo tikslas - palyginti skirtingas pastatų renovavimo alternatyvas, atsižvelgiant į energetinius, ekonominius ir aplinkos apsaugos kriterijus, vertinant renovacijos priemonių itaką per jų gyvavimo laiką. Pirmoji renovacijos alternatyva - pastatas renovuojamas, kad atitiktų reikalavimus, keliamus pastatų atitvarų šiluminėms charakteristikoms. Antroji renovacijos alternatyva - pastato atitvarų šiluminės charakteristikos, palyginti su galiojančiais reikalavimais, gerinamos $25 \%$. Trečioji alternatyva - pastato atitvarų šiluminès charakteristikos, palyginti su galiojančiais reikalavimais, gerinamos $50 \%$. Papildomai įvertinama galimybè visais trim atvejais naudoti atsinaujinančius energijos išteklius. Analizès rezultatai parodè, kad nagrinejjamu atveju gaunama energetinè ir aplinkosauginè nauda, kai vietoje esamos centralizuotai tiekiamos šilumos sistemos, kurioje šilumai gaminti pagrindinai naudojamas iškastinis kuras, ịrengiamas biomasès katilas. Ekonomiškai šios alternatyvos yra mažiau patrauklios. Galutinis alternatyvų pasirinkimas priklauso nuo sprendimų prièmejjo prioritetų.

Reikšminiai žodžiai: visuomeninis pastatas, renovacija, energijos vartojimo efektyvumas, ikūnytoji energija, gyvavimo ciklo analizè, gyvavimo ciklo kaštai, $\mathrm{CO}_{2}$ emisijos. 


\section{ПОИСК ОПТИМАЛЬНОГО РЕШЕНИЯ ПРИ РЕНОВАЦИИ ОБЩЕСТВЕННОГО ЗДАНИЯ С УЧЕТОМ ЭНЕРГЕТИЧЕСКИХ, ЭКОЛОГИЧЕСКИХ И ЭКОНОМИЧЕСКИХ КРИТЕРИЕВ}

\section{Л. Ужшилайтите, В. Мартинайтис}

Резюме

Изменение климата стало приоритетным вопросом на повестке дня энергетической и экологической политики Европейского Союза. Энергетическая эффективность и возобновляемые источники энергии являются основными мерами для уменьшения изменений климата. С этой точки зрения большое значение имеют здания, так как они в Европейском Союзе потребляют 40\% энергии. Это является причиной изменения отношения к оценке выгод от реновации существующих зданий. Ранее для принятия решения о реновации здания основным фактором являлась экономическая эффективность. Сегодня более актуальным является учет потребления энергии и сокращения выбросов парниковых газов.

Целью настоящей работы было сравнить различные варианты реконструкции здания с учетом энергетических, экономических и экологических критериев при оценке воздействия мер по реконструкции во время их жизненного цикла. Первый вариант - это реновация здания с целью улучшения его тепловых характеристик, доводя их до требований существующих строительных норм. Второй вариант - реновация здания с целью улучшения его тепловых характеристик на $25 \%$ по сравнению с требованиями существующих строительных норм. Третий вариант реновация здания с целью улучшения его тепловых характеристик на $50 \%$ по сравнению с требованиями существующих строительных норм. Кроме этого, во всех трех вариантах исследована возможность использования возобновляемых источников энергии.

Результаты анализа показали, что замена централизованного теплоснабжения, основанного главным образом на использовании ископаемых видов топлива, на котел с биомассой имеет преимущество с точки зрения окружающей среды и энергетики, однако экономическая привлекательность такой альтернативы довольно умеренна. Окончательный выбор вариантов зависит от приоритетов субъекта, принимающего решение.

Ключевые слова: общественное здание, реновация, эффективность применения энергии, воплощенная энергия, анализ жизненного цикла, стоимость жизненного цикла, эмиссия $\mathrm{CO}_{2}$.

Lina UŽŠILAITYTE். Master, doctoral student, Dept of Heating and Ventilation, Vilnius Gediminas Technical University (VGTU).

Doctoral student (energy and thermal engineering), VGTU, since 2005. Master of Energy, VGTU 2003. Publications: coauthor of 5 research papers. Conferences: participant of 4 conferences. Research interests: energy efficiency in buildings, life cycle analysis.

Vytautas MARTINAITIS. Dr Habil, Prof, Dept of Heating and Ventilation, Vilnius Gediminas Technical University (VGTU).

Dr Habil of Technical Sciences (energy and thermal engineering), Lithuanian Energy Institute (2000). Doctor of Technical Sciences (energy and thermal engineering), Polytechnic Institute of Belarus (1982). Publications: author of over 100 scientific publications. Research interests: energy use and supply systems for indoor climate of sustainable housing: thermodynamic, exergy and life cycle analysis; energy efficiency including policy; energy audit and renovation. 